\title{
Evaluation of antibacterial efficacy of Ocimum sanctum L. against certain bacterial species and phytochemical analysis
}

\author{
Aparajita Gupta 瓜 \\ Department of Microbiology, Dolphin PG College of Science and Agriculture, Chunni kalan, District Fatehgarh Sahib, Punjab, India. \\ Mandeep Kaur \\ Department of Microbiology, Dolphin PG College of Science and Agriculture, Chunni kalan, District Fatehgarh Sahib, Punjab, India.
}

\begin{tabular}{|c|c|}
\hline ARTICLE INFO & ABSTRACT \\
\hline $\begin{array}{l}\text { Received : } 12 \text { July } 2021 \\
\text { Revised : } 14 \text { September } 2021 \\
\text { Accepted : } 15 \text { November } 2021 \\
\text { Available online: } 19 \text { December } 2021 \\
\text { Key Words: } \\
\text { Agar well diffusion } \\
\text { Antibacterial activity } \\
\text { Ocimum sanctum } \\
\text { Phytochemical analysis } \\
\text { Phytoconstituents. }\end{array}$ & $\begin{array}{l}\text { In the present study antibacterial efficacy of aqueous and methanol extract } \\
\text { obtained from leaves and stem of Ocimum sanctum L. was evaluated against } \\
\text { certain test bacterial species viz. Escherichia coli, Pseudomonas aeruginosa, } \\
\text { Klebsiella pneumoniae, Staphylococcus aureus, and Bacillus cereus. It is a } \\
\text { traditional medicinal herb, commonly used for the treatment of various human } \\
\text { health disorders. The antibacterial activity was determined by using agar well } \\
\text { diffusion method. Among the solvent extracts tested, aqueous extract of leaves } \\
\text { exhibited higher antibacterial activity as compared to methanolic extract of } \\
\text { leaves. Maximum antibacterial activity was recorded } 17.6 \text { mm against Bacillus } \\
\text { cereus and minimum value was recorded } 14 \text { mm against } S \text {. aureus. Maximum } \\
\text { antibacterial efficacy of } O \text {. sanctum leaves was found } 7.3 \text { mm against } P \text {. } \\
\text { aeruginosa and minimum value was } 5 \mathrm{~mm} \text { against } B \text {. cereus in methanolic } \\
\text { extract. Similar trend has been observed in extract of stem of } O \text {. sanctum in } \\
\text { aqueous and methanolic solvent. The antibacterial efficacy has been found nil in } \\
\text { methanolic extract. However in aqueous extract moderate activity has been } \\
\text { recorded i.e. } 9.3 \text { mm against E.coli and minimum } 7.3 \text { mm against } K \text {. } \\
\text { pneumoniae. The trend of phytochemicals revealed non significant variation. } \\
\text { Phytochemical analysis of leaves and stem extracts of } O \text {. sanctum revealed the } \\
\text { presence of various phytoconstituents i.e. alkaloids, flavonoids, saponins, tanins, } \\
\text { glycosides. }\end{array}$ \\
\hline
\end{tabular}

\section{Introduction}

Medicinal plants possess biological properties and have been used for treatment of various health disorders since ancient times. Earliest documented record for the application of these drug plants is found in Rigveda (3500-1600 B.C) and Athravaveda (1200 B.C). India is probably the only country in world where medical science was developed thousands of years ago and these old medicine system are still employed. Herbal formulation and various medicinal plants are used extensively in Ayurveda treatment. $80 \%$ of the world's population depends wholly or partially on herbal medicines for their primary healthcare needs (Kunwar and Adhikari, 2005; Vidhani et al., 2016). Drug plants can be processed and used in variety of ways such as syrups, powders, tablets, ointment, or a liquid extract or a raw herb in powdered form
(Malapermal et al., 2017). Infectious diseases are the major cause of death in human beings. The discovery of antibiotics revolutionized medicine system and subsequently reduced the mortality rate (Subbiya et al., 2103; Taura et al., 2020). Antibiotics are secondary metabolites which are capable of killing or inhibiting the growth of microbes. During past few years, problem of Multiple Drugs Resistance (MDR) has been developed due to indiscriminate use of antimicrobial drugs in treatment of various human infections. In addition, antibiotics also cause adverse effects on host such as allergic reactions and immune suppression (Vidhani et al., 2016). Therefore there is a need to search for an alternative source in the form of plant based antimicrobial drugs for treatment of infectious 
diseases. Large number of workers have reported antimicrobial activity of different medicinal plants (Viji and Murugesan, 2010; Mittal et al., 2018; Farook et al., 2019). Antimicrobial properties of plants are due to the presence of biologically active phytochemicals such as phenols, alkaloids, flavonoids, terpenoids, tannins, lignins, glucosinolates and some secondary metabolites.

Ocimum sanctum linn. popularly known as "Tulsi" is a traditional medicinal plant of India which possess innumberable health benefits (Malapermal et al., 2017; Taura et al., 2020). Traditionally, crude extracts of tulsi were used as ayurvedic remedy for the treatment of inflammation, common cold, headache and stomach disorders. Tulsi is also used in dysentery, diarrhea and skin infections (Raghavendra et al., 2006; Malapermal et al., 2017). Ocimum sanctum possesses is knwn as "Elixir of life" because it possesses ethano pharmacological properties such as anti-diabetic anti-cancerous, analgesic, antiinflammatory, anti-microbial, antioxidant etc. Several secondary metabolites such as tannins, flavonoids, saponins, glycosides, terpenoids, fatty acid and phenol are found in tulsi leaf extract (Malapermal et al., 2017; Borah and Biswas, 2018).

\section{Material and Methods}

Collection of Plant material and preparation of Plant extracts: The Leaves and stem of Ocimum sanctum were collected from Govt. plant nursery, sector-23, chandigarh. The plant materials ( leaves and stem) were thoroughly washed and dried in shade. After proper drying, the leaves and stem of $O$. sanctum were grinded to form coarse powder. Extraction of test drug plant material i.e leaves and stem were done in different extracts (methanol and aqueous). 20 gram of grinded plant material was extracted using $250 \mathrm{ml}$ of extraction solvent for 24 $48 \mathrm{hrs}$ in Soxhlet extractor. Finally the extract obtained after extraction was subjected to filteration through sterile filter paper whatman no.1, Solution was evaporated under controlled conditions to dryness to get final volume of $20 \mathrm{ml}$. Therefore the extract solution obtained after evaporation was designated as $100 \%$ concentrated drug solution.

Collection of Test organisms: The bacterial test organisms used in the present study includes Staphylococcus aureus (MTCC code 3160), Pseudomonas aeruginosa (MTCC code 3542),
Escherichia coli (MTCC code 443), Klebsiella pneumoniae (MTCC code 9544) and Bacillus cereus (MTCC code 430). All the culture were procured from Microbial Type Culture collection (MTCC) of IMTECH Chandigarh, India.

Testing for antibacterial activity: Agar well diffusion method was used for evaluation of antibacterial activity (Bell and Grudy, 1968). The appropriate $100 \mathrm{ml}$ molten agar medium (Nutrient agar medium) was seeded with $2 \mathrm{ml}$ of bacterial suspension and poured into sterile petriplates. For agar well diffusion method, Sterile cork borer of $8 \mathrm{~mm}$ in diameter was bored in the medium to make wells in petriplates, $0.1 \mathrm{ml}(100 \mu \mathrm{m})$ extract solution was added to well. Whereas $0.1 \mathrm{ml}$ of methanol and sterilized water were used as control for methanolic and aqueous extract. These petriplates were then incubated at $37^{\circ} \mathrm{C}$ for 24 hours.

Phytochemical analysis: The preliminary phytochemical analysis was carried out for alkaloids, flavonoids, saponins, tanins and glycosides.

Test for alkaloids: Mayer's reagent was added to plant extract sample. If white precipitates forms, then it indicates the presence of alkaloids.

Test for Saponins: About $1 \mathrm{ml}$ of extract was diluted with $20 \mathrm{ml}$ of distilled water and shaken in gradually for 15 minutes. Appearance of $1 \mathrm{~cm}$ layer of foam indicate the presence of saponins.

Test for flavonoids: Add few drops of conc. $\mathrm{H}_{2} \mathrm{SO}_{4}$ in the sample extract If flavonoids present in sample, yellow colour appears in solution.

Test for tannins: Take $1 \mathrm{ml}$ of the extract and add few drops of $1 \%(\mathrm{w} / \mathrm{v})$ Ferric chloride $\mathrm{FeCl}_{3}$ solution. A green or brown color indicates the presence of tannins.

Test for glycosides by Keller- killiani test: Take $2 \mathrm{ml}$ of extract and $1 \mathrm{ml}$ of glacial acetic acid in a test tube and further add 3 drops $5 \%(\mathrm{w} / \mathrm{v})$ ferric chloride and concentrated sulphuric acid. Observe the test tube. Disappearance of reddish brown color at the junction of 2 layers and bluish green in upper layer indicates the presence of glycosides.

\section{Results and Discussion}

Results of antibacterial activity of methanol and aqueous extracts of O. sanctum against Escherichia coli, Pseudomonas aeruginosa, Klebsiella pneumoniae, Staphylococcus aureus, and Bacillus 342 
cereus were studied and results have been presented in the table $1 \& 2$ respectively. Results revealed that antibacterial activity of aqueous extract of leaves of $O$. sanctum were found stronger than methanolic extract against all test bacterial species. Maximum antibacterial activity in terms of inhibition zone was recorded at $100 \%$ in aqueous extract against $B$. cereus $(17.6 \mathrm{~mm})$ followed by $K$. pneumoniae 16.3 $\mathrm{mm}, P$. aeruginosa $15.6 \mathrm{~mm}, E$. coli $15.3 \mathrm{~mm}$ and minimum value was observed against $S$. aureus 14 $\mathrm{mm}$. But methanolic extract showed poor antibacterial activity compared to aqueous and could stand below only upto range of $50 \%$ against all test bacterial species i.e. $7.3 \mathrm{~mm}$ in $P$. aeruginosa followed by $6.0 \mathrm{~mm}$ in $S$. aureus, 5.6 $\mathrm{mm}$ in $K$. pneumonia and minimum $5 \mathrm{~mm}$ in $B$. cereus (Table 1$)$.

Table 1: Antibacterial activity of methanolic and aqueous extract of leaves of O.sanctum against certain test bacterial species

\begin{tabular}{|l|l|l|l|}
\hline $\begin{array}{l}\text { Type of } \\
\text { extract }\end{array}$ & $\begin{array}{l}\text { Extract } \\
\text { Conc. }\end{array}$ & $\begin{array}{l}\text { Test } \\
\text { organisms }\end{array}$ & $\begin{array}{l}\text { Effective zone } \\
\text { of inhibition } \\
(\mathbf{m m})\end{array}$ \\
\hline Methanol & $100 \%$ & E.coli & 5.3 \\
& $100 \%$ & P.aeruginosa & 7.3 \\
& $100 \%$ & K.pneumoniae & 5.6 \\
& $100 \%$ & S.aureus & 6 \\
& $100 \%$ & B.cereus & 5 \\
\hline Aqueous & $100 \%$ & E.coli & 15.3 \\
& $100 \%$ & P.aeruginosa & 15.6 \\
& $100 \%$ & K.pneumoniae & 16.3 \\
& $100 \%$ & S.aureus & 14 \\
& $100 \%$ & B.cereus & 17.6 \\
\hline Control & $100 \%$ & Nil \\
\hline
\end{tabular}

Table 2: Antibacterial activity of methanolic and aqueous extract of stem of $O$.sanctum against certain bacterial species

\begin{tabular}{|l|l|l|l|}
\hline $\begin{array}{l}\text { Type of } \\
\text { extract }\end{array}$ & $\begin{array}{l}\text { Extract } \\
\text { Conc. }\end{array}$ & $\begin{array}{l}\text { Test } \\
\text { organisms }\end{array}$ & $\begin{array}{l}\text { Effective zone } \\
\text { of inhibition } \\
\text { (mm) }\end{array}$ \\
\hline Methanol & $100 \%$ & E.coli & -- \\
& $100 \%$ & P.aeruginosa & -- \\
& $100 \%$ & K.pneumoniae & -- \\
& $100 \%$ & S.aureus & -- \\
\hline Aqueous & $100 \%$ & B.cereus & -- \\
& $100 \%$ & E.coli & 9.3 \\
& $100 \%$ & P.aeruginosa & 8.3 \\
& $100 \%$ & K.pneumoniae & 7.3 \\
& $100 \%$ & S.aureus & 8.6 \\
& $100 \%$ & B.cereus & 8.6 \\
\hline Control & $100 \%$ & Nil \\
\hline
\end{tabular}

Antibacterial activity of methanolic and aqueous extract of stem part of $O$. sanctum against certain bacterial species has been presented in table- 2 . Antibacterial activity has been found zero (nil) in methanolic extract against all bacterial test species. However, the aqueous extract of stem showed antibacterial activity upto moderate level, $9.3 \mathrm{~mm}$ in E. coli followed by 8.6 in $S$. aureus and B. cereus and minimum was observed against $K$. pneumoniae $7.3 \mathrm{~mm}$ (Table 2). Results of Phytochemical studies of methanol and aqueous extract of leaves and stem of $O$. sanctum studies have been given in table $3 \& 4$ respectively. Results of phytochemical studies of leaves of $O$. sanctum of methanolic extract had shown the presence of alkaloid and tannins but flavonoid, saponins and glycosides were absent. In aqueous extract of $\mathrm{O}$. sanctum leaves, tannin, saponin, flavonoids were detected but alkaloids and glycosides were absent (table 3). In stem part of O. sanctum methanolic and aqueous extract revealed that in both extract, only four chemicals were detected in each. Alkaloids, tannins, saponins and glycosides were found in methanolic extract but flavonoids were absent (table 4). But in aqueous extract only glycosides was absent and rest chemicals were same as in methanol extract were recorded (table 4).

Results revealed that alkaloids and tannins were present in methanolic extract of $O$. sanctum leaves but tannins, flavonoids and saponins were found in the aqueous extract (table 3). Where in case of methanolic and aqueous extract of stem of $O$. sanctum shows the presence of more phytochemicals than $O$. sanctum leaves (table 4). Glycosides were found in methanolic leaves and stem extract but flavonoids were absent while in aqueous extract glycosides was absent (table 4).

Albeit the presence of different chemical components found in the study presented in table 3 and table 4 revealed presence of three components i.e. tannins, flavonoids and saponins in aqueous extract but only alkaloids and tannins in methanolic extract has been found (table 3), it seems that presence of flavonoids and saponins in aqueous extract might be playing as a booster role in order to making stronger antibacterial property of leaves extract in water as well as quantity of these chemicals may also be playing role, which are more soluble in water. Besides this some volatiles will 
Table 3: Phytochemical screening of leaves extract of O. sanctum

\begin{tabular}{|l|l|c|c|}
\hline $\begin{array}{l}\text { Chemical } \\
\text { Constituents }\end{array}$ & $\begin{array}{l}\text { Test } \\
\text { performed }\end{array}$ & $\begin{array}{l}\text { Methanol } \\
\text { extract }\end{array}$ & $\begin{array}{l}\text { Aqueous } \\
\text { extract }\end{array}$ \\
\hline Alkaloids & Mayer's test & + & - \\
\hline Tannins & $\begin{array}{l}\text { Ferric } \\
\text { chloride test }\end{array}$ & + & + \\
\hline Flavonoids & $\begin{array}{l}\text { Sulphuric } \\
\text { acid test }\end{array}$ & - & + \\
\hline Saponins & Foam test & - & + \\
\hline Glycosides & $\begin{array}{l}\text { Keller's } \\
\text { Killiani test }\end{array}$ & - & - \\
\hline
\end{tabular}

Table 4: Phytochemical screening of stem extract of O. sanctum

\begin{tabular}{|l|l|c|c|}
\hline $\begin{array}{l}\text { Chemical } \\
\text { Constituents }\end{array}$ & $\begin{array}{l}\text { Test } \\
\text { performed }\end{array}$ & $\begin{array}{l}\text { Methanol } \\
\text { extract }\end{array}$ & Aqueous extract \\
\hline Alkaloids & Mayer's test & + & + \\
\hline Tannins & $\begin{array}{l}\text { Ferric } \\
\text { chloride test }\end{array}$ & + & + \\
\hline Flavonoids & $\begin{array}{l}\text { Sulphuric } \\
\text { acid test }\end{array}$ & - & + \\
\hline Saponins & Foam test & + & + \\
\hline Glycosides & $\begin{array}{l}\text { Keller's } \\
\text { Killiani test }\end{array}$ & + & - \\
\hline
\end{tabular}

- ' '+' indicates the presence of plant constituents.

- ' - ' indicates the absence of plant constituents.

also be responsible for antibacterial property. Various information are available that phytochemicals present in plant materials play significant role in inhibition in the growth of microbial pathogens, Antimicrobial nature of $\mathrm{O}$. sanctum plant is due to the chemical components recorded in the leaves and stem, variations recorded in the antimicrobial activity in leaves and stem extract may be due to solubility of chemicals in the solvent. Degree of more activity in leaves of $\mathrm{O}$. sanctum than stem may be due to presence of more

\section{References}

Bell, S. C., \& Grundy, W. E. (1968). Preparation of agar wells for antibiotic assay. Applied Microbiology, 16(10), 16111612.

Borah, R., \& Biswas, S. P. (2018). Tulsi (Ocimum sanctum), excellent source of phytochemicals. International Journal of Environment, Agriculture and Biotechnology, 3(5), 265258 .

Farook, M. A., Ali, A. M., Mohamed, H. M., Subash, V., Santhosh, G., Kumar, M. P., \& Ahmed, I. A. (2019). Phytochemical screening, antibacterial activity and antioxidant activity of Ocimum sanctum leaf concentration of components, synthesis in leaves and volatile etc than stem. Possibilities of more solubility of chemicals in water may be the cause of upperhand of antimicrobial property of aqueous extract. Presence of some of these phytochemicals play a very significant role in the inhibition of microbial growth in different ways. Mamtha et al. (2004) reported that tannins causes inhibition in the cellwall sysnthesis by forming irreversible complexes with prolene rich protein. Study indicates that presence of these biological active phytochemicals in both extract may be responsible for their antimicrobial activity. Similarly saponins also have been reported as active inhibitor, these chemicals may act by targeting one or more parts af bacterial cells separately or collectively which ultimately results on inhibition of bacterial growth or lysis.

\section{Conclusion}

The presence of certain biologically active phytochemicals in leaves and stem extract of $O$. sanctum may be responsible for antimicrobial properties of plant. Plant extracts are found abundant in flavonoids, saponins, tannins, glucosides and alkaloids. Our findings support the folkloric usage of $O$. sanctum. $O$. sanctum is a significant natural antimicrobial agent and can be recommended for the treatment of various microbial infections.

\section{Acknowledgement}

The authors are thankful to the Principal and Managing committee of the college for providing necessary research facilities in the Department.

extract. Journal of Pharmacognosy and Phytochemistry, 8(3), 560-565.

Kunwar, R. M., \& Adhikari, N. (2005). Ethnomedicine of Dolpa district, Nepal: the plants, their vernacular names and uses. Lyonia, 8(1), 43-49.

Malapermal, V., Botha, I., Krishna, S. B. N., \& Mbatha, J. N. (2017). Enhancing antidiabetic and antimicrobial performance of Ocimum basilicum, and Ocimum sanctum (L.) using silver nanoparticles. Saudi Journal of Biological Sciences, 24(6), 1294-1305. 
Mamtha, B., Kavitha, K., Srinivasan, K. K., \& Shivananda, P. G. (2004). An in vitro study of the effect of Centella

Mittal, R., Kumar, R., \& Chahal, H. S. (2018). Antimicrobial activity of Ocimum sanctum leaves extracts and oil. Journal of Drug Delivery and Therapeutics, 8(6), 201204.

Raghavendra, M. P., Satish, S., \& Raveesha, K. A. (2006). Phytochemical analysis and antibacterial activity of Oxalis corniculata; a known medicinal plant. My science, 1(1), 7278.

Subbiya, A., Mahalakshmi, K., Pushpangadan, S., Padmavathy, K., Vivekanandan, P., \& Sukumaran, V. G. (2013). Antibacterial efficacy of Mangifera indica L. kernel and Ocimum sanctum L. leaves against Enterococcus faecalis dentinal biofilm. Journal of conservative dentistry: $J C D, 16(5), 454$. asiatica [Indian pennywort] on enteric pathogens. Indian Journal of Pharmacology, 36(1), 41.

Taura, A. D. D. D. W., Musa, D. A., Ayuba, S. S., Shu'aibu, M., \& Muhammad, A. U. (2020). Evaluation of antibacterial activity of and Momordica charantia, Ocimum sanctum Prosopis juliflora against some selected bacteria. Asian Journal of Pharmacy and Pharmacology, 6(3), 217-223.

Vidhani, S. I., Vyas, V. G., Parmar, H. J., Bhalani, V. M., Hassan, M. M., Gaber, A., \& Golakiya, B. A. (2016). Evaluation of some chemical composition, minerals fatty acid profiles, antioxidant and antimicrobial activities of Tulsi (Ocimum sanctum) from India. American Journal of Food Science and Technology, 4(2), 52-57.

Viji, M., \& Murugesan, S. (2010). Phytochemical analysis and antibacterial activity of medicinal plant Cardiospermum halicacabum Linn. J Phytol, 2(1), 68-77. 